Volume I Tahun 2021

November 2021
E-ISSN: 2808-5361

http://e-journal.fkmumj.ac.id/
Proceeding The First

Muhammadiyah

Internasional- Public Health

and Medicine Conference

\title{
ANALYSIS OF COVID-19 VACCINATION COVERAGE IN THE ELDERLY IN THE WORK AREA OF CIJAYANTI PUSKESMAS
}

\author{
Fitria Istina Dewi \\ Faculty of Public Health, Muhammadiyah University of Jakarta \\ K.H. Ahmad Dahlan Street, Cireundeu, Ciputat, Jakarta Selatan 15419 \\ Email: drgdewifitri@gmail.com
}

\begin{abstract}
The elderly (elderly) is one of the groups that are susceptible to being infected with Corona Virus Diseases 19 (Covid 19). Therefore, the elderly group is a priority group to get the Covid 19 vaccination. This study aims to describe and analyze the scope of the implementation of the COVID-19 vaccination program for the elderly in the Cijayanti Health Center work area which is still low. This research is a descriptive study with a qualitative approach. Data collection was carried out by in-depth interviews with midwives as the holder of the immunization program as the main informant, the doctor as the head of the vaccinator team, the holder of the elderly program, the Cijayanti, and Bojong Koneng village offices, and 10 elderly people. The achievement of the elderly vaccination at the Cijayanti Health Center was only $10.8 \%$ of the total number of elderly people. There are several obstacles in collecting data on elderly who are willing to be vaccinated because of the influence of the environment, both from their immediate family/children and from the surrounding community. Environmental factors, namely family support, community leaders, religious leaders greatly influence the participation of the elderly in covid vaccination 19.
\end{abstract}

Keywords: Covid 19, Coverage, Elderly, Disease, Vaccination. 


\section{INTRODUCTION}

The population aged 60 years and over is the fastest growing in the world, due to decreased fertility and increased life expectancy. This phenomenon is known as population aging which occurs all over the world. In 2015, people aged 60 years or over were 901 million people or $12 \%$ of the world's population. Population aged 60 years and over increased to $3.26 \%$ per year. Along with the increase in life expectancy, it is estimated that the number of elderly people will also increase. According to the United Nations, the projection of the number of elderly people in the world in 2025 will reach $77.37 \%$ of the world's population.

According to WHO, in Southeast Asia, the elderly population is $8 \%$ or around 142 million people. The success of health development in Indonesia has an impact on decreasing birth rates, morbidity and mortality rates as well as an increase in Life Expectancy (UHH) at birth. Indonesia will enter the aging population marked by the percentage of the elderly (elderly) which will reach $10 \%$ in 2020. According to the 2019 Central Statistics Agency, of all the elderly in Indonesia, young elderly (60-69 years) far dominate with a magnitude reaching 63.82 percent, followed by middle elderly (70-79 years) at 27.68 percent and elderly seniors (80+ years) by 8.50 percent.

Basic Health Research data from the Ministry of Health in 2018 in the elderly are noncommunicable diseases such as heart disease, diabetes, stroke, rheumatism, and injury. Along with the decline in the immune system, the elderly are also vulnerable to infectious diseases such as respiratory infections, diarrhea, and pneumonia. With increasing age, the body will experience various decreases due to the aging process, almost all organ functions, and movement decrease, followed by decreased immunity as a body protector that does not work as well as when it was young. This is the reason why the elderly (elderly) are susceptible to various diseases, including COVID-19 which is caused by the Sars-Cov-2 virus. A weakened immune system plus the presence of chronic disease can increase the risk of COVID-19 in the elderly, both the risk of coronavirus infection and the risk of this virus causing severe disturbances, even death.

An increase in the risk of COVID-19 in the elderly, both the risk of coronavirus infection and the risk of this virus causing severe disturbances, even death.

An elderly group is a group that is susceptible to disease, the government has prioritized the elderly group to prioritize getting the Covid 19 vaccination after the previous target was health workers. Vaccination for the elderly will begin in the provincial capital for all provinces 
in Indonesia, prioritized in Java - Bali. Vaccination of the elderly is prioritized, especially in areas with high Covid-19 cases. The goal is that even if the elderly are exposed to the coronavirus, their health conditions will not drop or have severe symptoms so that the number of people who have to be hospitalized can decrease. It is also hoped that it can reduce the death rate because it is proven that regardless of the type of vaccine, it can prevent someone from experiencing severe symptoms or dying.

Vaccination for the elderly in Bogor Regency has started for the first time on March 3, 2021, with a total target of 339,958 elderly people who will be vaccinated, and as of early April 2021 , only 20,852 people have been injected with the vaccine or, about $6 \%$ of the existing elderly. The influence from outside and from within the elderly has a big role in influencing the elderly to participate in vaccinations. In addition, there are also several obstacles in the implementation of vaccination for the elderly. This has prompted researchers to conduct further studies. What is the description of the implementation of the COVID-19 vaccination program for the elderly in the work area of the Cijayanti Health Center?

The expected benefit from this research is that it can provide coverage information and constraints in the implementation of vaccination for the elderly so that it can be taken into consideration in achieving the successful implementation of the covid 19 vaccination program for the elderly at Cijayanti Health Center.

\section{METHODS}

This type of research is descriptive with a qualitative approach. Data collection was carried out by in-depth interviews based on purposive sampling criteria in the Cijayanti Community Health Center working area covering 2 villages, namely Cijayanti village and Bojong Koneng village from early March 2021 to early April 2021.

The informants in this study were the midwife as the holder of the immunization program as the main informant, the doctor as the head of the vaccinator team, the holder of the elderly program, the Cijayanti and Bojong Koneng village offices and, 10 elderly people.

\section{RESULTS AND DISCUSSION}

There are 2 villages in the Cijayanti Health Center. In these two villages, some residents live in housing, and some live in rural areas, where this has different social, cultural, and behavioral impacts. The number of elderly population can be seen in table 1. 
Table 1. The number of Elderly Population

\begin{tabular}{cccccccc}
\hline \multirow{2}{*}{ No } & Village Name & \multicolumn{3}{c}{$\begin{array}{c}\text { Number of elderly> 60 } \\
\text { years }\end{array}$} & \multicolumn{3}{c}{$\begin{array}{c}\text { The number of elderly } \\
\text { people> 70 years }\end{array}$} \\
\cline { 3 - 7 } & & $\mathbf{L}$ & $\mathbf{P}$ & JML & L & P & JML \\
\hline 1 & Cijayanti & 325 & 298 & 623 & 252 & 241 & 292 \\
2 & Bojong Koneng & 310 & 273 & 583 & 131 & 122 & 253 \\
& Total & 635 & 571 & $\mathbf{1 2 0 6}$ & 282 & 263 & $\mathbf{5 4 5}$ \\
\hline
\end{tabular}

We know that the number of elderly patients in the Cijayanti Public Health Center area is 1,751 people or about $5 \%$ of the total population in the working area of the Cijayanti Health Center.

Vaccination of the elderly is a priority program for the second phase of the government after vaccination for health workers. Vaccination of the elderly in Bogor Regency began in early March 2020. The elderly group was chosen as the priority vaccine because the elderly are more vulnerable when infected with COVID-19. The Ministry of Health has confirmed that the elderly (elderly) can receive the Covid-19 vaccine injection. This is stated in a circular letter (SE) numbered HK.02.02 / I / 368/2021 concerning the Implementation of Covid-19 Vaccination in the Target Group for the Elderly, Comorbids, and Covid-19 Survivors, as well as Targets Delayed to the Heads of the Provincial Health Service, Regencies / Cities concerned. implementation of the Covid-19 vaccination. Covid-19 vaccination can be given to the age group of 60 years and over, comorbid, COVID-19 survivors, and breastfeeding mothers with additional history taking first. Vaccination must still follow the technical guidelines for the implementation of Covid-19 vaccination. Vaccination in the age group of 60 years and over was given as many doses with an interval of 28 days ( 0 and 28$)$.

Covid-19 vaccination participants in the elderly group still have to undergo screening before injections are carried out. Screening is carried out by asking some questions to the elderly as follows:

1. The elderly will be asked if they have difficulty climbing 10 steps.

2. The elderly will also be asked if they often feel tired.

3. The elderly will be asked whether they suffer from five or more of these 11 diseases: hypertension, diabetes, cancer, chronic lung disease, heart attack, congestive heart failure, chest pain, asthma, joint pain, stroke, and kidney disease.

4. The elderly were asked if they had difficulty walking about 100 to 200 meters. 
5. The elderly were asked whether they had experienced significant weight loss in the past year.

If or there are three or more yes answers to the five questions vaccination cannot be administered to elderly participants.

The same circular also stipulates six general screening questions that will be asked to vaccination participants. The six are:

1. Body temperature conditions. If the body temperature is above 37.5 degrees Celsius, then vaccination is postponed until the target is cured.

2. Blood pressure. If the blood pressure is above $180 / 110 \mathrm{mmHg}$, the blood pressure measurement is repeated 30-60 minutes later. If the blood pressure is still high, the vaccination is postponed until the blood pressure is controlled.

3. About contact with Covid-19 positive individuals. Have you ever been in contact with someone who is under examination/confirmed/under treatment due to Covid-19 within the last 14 days? If the answer is yes, then it will be followed by the question if you have had symptoms of breath in the last 7 days. If the answer is yes, then the vaccination is postponed until 14 days after symptoms appear.

4. For the first dose of vaccination, participants will be asked if they have a history of severe allergies such as shortness of breath, swelling or urticaria all over the body, or other severe reactions to the vaccine. If the answer is yes, the vaccination is given at the hospital.

5. For the second dose of vaccination, participants will be asked whether they have a history of severe allergies or experience symptoms of shortness of breath, swelling, and urticaria throughout the body after being vaccinated against Covid-19. If the answer is yes, then the second dose of vaccination will no longer be given

6. Regarding other vaccinations. Participants will be asked if they received other vaccinations in the past one month or so. If the answer is yes, then vaccination is postponed until one month after the previous vaccination. 
Covid-19 vaccination coverage for the elderly in the work area of the Cijayanti Health Center, which was carried out from March 6 to April 6, 2021, compared to the total number of elderly people, the following data were obtained:

Table 2. Data on the Number of Elderly who Have Been Vaccinated.

\begin{tabular}{lcc}
\hline \multicolumn{1}{r}{ Elderly } & Frequency & Percentage \\
\hline It's been vaccinated & 189 & 10.8 \\
Not vaccinated yet & 1.562 & 89.2 \\
Total & 1.751 & 100.0
\end{tabular}

From the data obtained during the vaccination period in the period of March 6 to April 6,2021 , the participation rate of the elderly in Covid-19 vaccination is still relatively low when compared to the number of elderly populations in the work area of the Cijayanti Health Center. Of the 1.751 elderly people, only 189 were vaccinated at dose 1 and dose 2 , or about $10.8 \%$. This is in line with the scope of the Covid-19 vaccination for the elderly (elderly) in Bogor Regency which is still far from expectations. This is because, of the 339,958 elderly who are registered as vaccine recipients, only about 20 thousand elderly have received the first dose of the Covid-19 vaccine, or $7 \%$ of the number of seniors registered as recipients of the Covid-19 vaccine.

The same thing was conveyed by the Director-General of Disease Prevention and Control Maxi Reni Rondonuwu. The implementation of vaccination for the elderly at the national level is still far from expectations. Of the total target of 21.6 million elderly, as of March 30, 2021, the number of elderly people who have been injected with the new vaccine is around 1.5 million / people, or around 6.9\%.

Here the elderly have a very high risk and vulnerability. What's more, if infected, the risk of the virus worsening their health is also high. To note, the morbidity and mortality rate of the elderly due to contracting or being infected with Covid-19 is 50 percent compared to those who are not infected. The fatality rate in the age group 50-69 years is higher than non-elderly

Based on the results of the interviews, several aspects that are considered as obstacles in the implementation of vaccination for the elderly include:/ data collection on the elderly and environmental factors.

Data on elderly targets has been obtained from elderly program holders, but there are obstacles when collecting data on elderly people who will participate in the vaccination. Data collection on the elderly who will be vaccinated involves the village, RT / RW, and cadres. The participation of the elderly who live in housing to be vaccinated is very high, but in contrast to 
the elderly who live in rural, where the participation to be vaccinated is very low. Meanwhile, the number of elderly people living in rural/village areas is much higher, so that it has an impact on the vaccination coverage for the elderly at the Cijayanti Public Health Center. After obtaining the target number, the Puskesmas will plan the needs and logistics of vaccines in the form of vaccines, alcohol swabs, safety boxes, PPE, disinfectants, etc. Puskesmas verify data obtained from the p-care application as well as data from RT / RW, cadres, or village officials. Puskesmas conduct socialization about vaccines and implementation procedures to crosssectoral and community levels

Next is the environmental factor. In this study, the environment is everything that has a major influence on program implementation, in this case, the Covid 19 vaccination program for the elderly, which includes support from family and the wider community such as religious leaders, community leaders, and the general public around them. From the results of interviews with the elderly, several answers that affect the vaccination participation for the elderly:

1. easy access to vaccination sites. With their physical decline, the elderly need a vaccination site that is easily close and easy to reach. Lansia belum mendapat informasi yang utuh tentang pentingnya vaksin

2. Family support,

3. Difficulty in mobilizing due to physical barriers

4. Negative beliefs and experiences from family members/relatives/friends.

5. Concerns about vaccine raw materials and vaccine side effects.

\section{CONCLUSION AND SUGGESTIONS}

From the results of the research that has been done, the following conclusions can be drawn:

1. The coverage of the elderly who have been vaccinated is 189 people or $10.8 \%$ of the total number of elderly in the working area of the Cijayanti Health Center $(1,751$ people).

2. Obstacles to the implementation of COVID-19 vaccination in the elderly include data collection and environmental factors. The data collection of elderly who are willing to participate in vaccination activities is still very low, especially elderly who live in rural areas compared to elderly who live in homes, while the number of elderly who live in rural areas is more so that it will affect the results of Puskesmas coverage.

3. Environmental factors, namely easy access to vaccination sites, lack of information, beliefs, worries/fears, and support from family, religious leaders, community leaders, 
and their surroundings greatly influence the participation of the elderly in Covid 19 vaccination.

4. The need for the role of RT/RW village officials, religious leaders, and community leaders in collaboration with Puskesmas to provide information about the causes, transmission, and prevention of covid 19, including vaccination. So it is hoped that it will change the thinking of the elderly and their families about the importance of the covid 19 vaccination.

\section{THANK-YOU NOTE}

Thanks are given to the Cijayanti and Bojong Koneng Villages and the Cijayanti Health Center who have supported/assisted by providing data on the elderly and data on Covid-19 vaccination coverage for the elderly in the Cijayanti Health Center work area.

\section{REFERENCES}

1. Kementerian Kesehatan Republik Indonesia, Survei Penerimaan Vaksin COVID-19 di Indonesia, Jakarta, 2020.

2. Betapa Rentannya Lansia di Tengah Pandemi Corona", 27 Maret 2020, https://kumparan.com/ pandangan-jogja/betaparentannya-lansia-ditengah pandemi-corona1t6SreDRfHe/ full, diakses 13 Mei 2020.

3. Ditjen P2P Penyakit Menular Kementerian Kesehatan. 2020. Jaga agar Lansia terhindar dari COVID -19, Jakarta

4. Badan Pusat Statistik, 2019. Statistik Penduduk Lanjut Usia 2019. Jakarta: BPS.

5. Badan Pusat Statistik. 2020. Angka Harapan Hidup Penduduk Beberapa Negara Tahun 1995-2015. Jakarta: BPS.

6. Guslinda, Nova Fridalni, Aida Minropa, Faktor yang Berhubungan dengan Tingkat Kecemasan Lansia pada Masa Pandemi Covid 19, Jurnal Keperawatan, 2020.

7. 7 Kementerian Pemberdayaan Perempuan dan Perlindungan Anak. (2020). Panduan Perlindungan Lanjut Usia Berperspektif Gender Pada Masa Covid-19. Jakarta, 2020.

8. 8.Karyono.Penanganan Dan Pencegahan Pandemi Wabah Viris Corona (Covid-19) Di Kabupaten Indramayu. Jurnal Kolaborasi Resolusi Konflik.2020

9. 9.Syafrid dan Ralang Hartat. Bersama Melawan Virus Covid-19 di Indonesia. Jurnal Sosial \& Budaya Syar-i.2020

10. 10.Notoatmodjo, S. (2017). Metodologi Penelitian Kesehatan. Jakarta: Rineka Cipta. 


$$
\text { E-ISSN: 2808-5361 }
$$
http://e-journal.fkmumj.ac.id/
Proceeding The First Muhammadiyah Internasional- Public Health and Medicine Conference

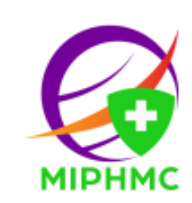

11. 11.Kementerian Kesehatan RI, Pencegahan dan pengendalian coronavirus disease (Covid19), Jakarta, dirjen pencegahan dan pengendalian penyakit,2020.

12. Ekpenyong B, Obinwanne CJ, Ovenseri ogbomo G, Ahaiwae K, Lewis OO, Echendu DC, Assessment of knowledge, practice and guidelines towards the novel covid-19. 
Volume I Tahun 2021

November 2021
E-ISSN: 2808-5361

http://e-journal.fkmumj.ac.id/
Proceeding The First

Muhammadiyah

Internasional- Public Health and Medicine Conference 